\title{
Correspondence
}

Editor: Greg Wilkinson

Contents: Psychiatric Munchausen's syndrome: a College register?/Down's syndrome with mania/ Dangerous delusions: the 'Hollywood' syndrome/ Response to biological treatment/The pathogenesis of depersonalisation/Age disorientation in chronic schizophrenia/Psychiatric symptoms in transsexualism/Risk factors in schizophrenia/Therapy-resistant depression/Prescribing for the long-term mentally ill/ Schizophrenic thought disorder/Supportive psychotherapy: a contradiction in terms?/Mystical-ecstatic and trance states/Psychogeriatric liaison referrals/ Failure to convulse with ECT/Cerebral ventricular enlargement in chronic schizophrenia/The concept of disease in psychiatry/Combined mianserin and tranylcypromine/Psychotropic medication and antisocial behaviour in a mental handicap hospital/ De Clérambault's syndrome in unipolar depression/ Carbamazepine and ECT/Dressing disorder

\section{Psychiatric Munchausen's Syndrome: A College Register?}

SIR: I am inclined to agree with the suggestion made by Markantonakis \& Lee (Journal, June 1988, 152 , 867) of keeping a register of Munchausen cases. I came to a similar conclusion when considering a case presenting with feigned epilepsy and amnesia (Jones \& Horrocks, 1987), and suggested keeping a national computerised database of such cases.

I came to this view as I do not believe that these cases are treatable by other methods, and they can be a drain on limited medical resources. From an ecological viewpoint, these cases may be seen as filling a 'niche' provided by the health services in our society. Thus it may not be possible in a conventional manner to 'treat' the 'patient', and the management of Munchausen cases may require a fundamentally different approach.

As such cases may cross the boundaries between various specialities, including psychiatry, surgery, and medicine, then it may be more advantageous to have a central register, e.g. in the Department of Health and Social Security. Thus one could have information on 'hospital addicts', much as there is now a register of drug addicts. It would be relatively cheap and cost-effective to keep a computerised database of such cases. The savings could be great in terms of unnecessary investigations and operations avoided, staff time saved, etc. A cost-benefit analysis might give some idea of the actual savings involved.

The North Wales Hospital

J. R. JONES

Denbigh

Clwyd LL16 5SS

\section{Reference}

JONES, J. R. \& Horrocks, F. A. (1987) Fictitious epilepsy associated with amnesia. British Journal of Psychiatry, 150, 257-258.

\section{The Mentally Handicapped Criminal Offender}

SIR: Kearns \& O'Connor (Journal, June 1988, 152, 848-851) state that little attention has been paid to analysis of the types of offences committed, and their article illustrates well the range of offences which used to lead to hospital admission of the mentally handicapped offender.

Studies which we carried out for the six years 1968-73 showed that out of 607 long-stay hospital admissions there were 222 for offences against the person, of which $\mathbf{8 8}$ were sexual, and a further $\mathbf{9 8}$ for offences against property (Primrose, 1974). There were also 98 admissions for 'antisocial behaviour', mostly of a non-criminal character.

Not all of those committing offences were admitted because of Court proceedings, for in many cases these were not proceeded with on the understanding that the person was being admitted to hospital. The actual number of Court Orders for the six-year period was 111, which compares with 104 in the six years 1956-61. The major changes quoted by Drs Kearns \& O'Connor arising between 1961 and 1977 came largely after 1973, for reasons which I have outlined previously (Primrose, 1984).

\section{Garngaber Avenue}

David A. Primrose

Glasgow G66 4LL 
References

Primrose, D. A. (1974) The changing pattern of admissions to a mental deficiency hospital. Health Bulletin. 32, No. 5, 1-3.

(1984) Changing sociological and clinical patterns in mental handicap. British Journal of Psychiatry, 144, 1-8.

\section{Down's Syndrome with Mania}

SIR: Please permit me to make some comments on Cook \& Leventhal's letter (Journal, May 1988, 152, 721-722) in response to my previous letter (Journal, March 1988, 152, 436-437).

Firstly, while I agree with them that developmental considerations per se might modify the clinical presentation of psychiatric illness, this is mainly in the area of symptomatology requiring the use of language. The biological features, such as altered appetite, altered sleep, and restless overactivity, are not affected as demonstrated by cases of mania associated with other conditions of mental retardation. In my own practice I have treated full-blown manic cases in the setting of mental retardation due to other causes. Even in Down's syndrome of borderline intelligence I have not come across manic illness. I do not believe the altered picture in Down's syndrome is solely due to developmental delays.

Secondly, the post-mortem studies, although limited, do point towards noradrenergic cell loss even in younger Down's syndrome cases (Mann et al, 1985). This, in association with clinical experience and epidemiological study (Singh \& Zolese, 1986), is suggestive of association between Down's syndrome and lack of mania.

Thirdly, in their letter Drs Cook \& Leventhal seem to be retracting from their original statement. In the original article (Journal, February 1987, 150, 249 $250)$ they wrote, "In fact a case can be made for a heightened association of Down's syndrome and bipolar affective illness". They go on to quote the Prange et al (1974) hypothesis.

Finally, I agree with Drs Cook \& Levanthal that further epidemiological and neurochemical information is required to help clarify the situation.

IQBAL SINGH

Leavesden Hospital

College Road

Abbots Langley

Herts WDS ONU

\section{References}

Mann, D. M. A., Yates, P. O., Marcynuik, B. \& RAvindra, C. R. (1985) Pathological evidence for neurotransmitter deficits in Down's syndrome of middle age. Journal of Mental Deficiency Research, 29, 125-135.

Prange, A. J., Wilson, I. C., LynN, C. W. et al (1974) Tryptophan in mania. Archives of General Psychiatry, 30, 56-62.
SINGH, I. \& ZOLESE, G. (1986) Is mania really incompatible with Down's syndrome? British Journal of Psychiatry, 148, 613-614.

\section{Dangerous Delusions: The 'Hollywood Phenomenon'}

SiR: Shubsachs \& Young (Journal, May 1988, 152, 722), in reporting two cases of a variant of a delusional misidentification syndrome which they have termed the 'Hollywood phenomenon', expressed the view that this symptom was under-reported and not specific for affective disorders. We here report an example of this symptom occurring in a paranoid schizophrenic patient. As in one of their cases, the symptom was directly associated with violence to others.

Case report: GW, A 23-year-old unemployed man with a history of a previous admission for an acute schizophrenic psychosis, was remanded in custody on charges of malicious wounding, burglary, and possession of an offensive weapon. For 5 months he had felt that he was being filmed by hidden cameras and that newspaper articles had a special significance for him. He believed that people spoke to him in codes. Prior to the offence he had not slept and felt "high and excited". He felt that he was performing theatre, that he had been hypnotised and that codes had been put into his mind. On the night of the offences he smashed windows, believing it was part of the filming exercise. He defecated in a bin, returned to his flat, and cooked some stew. He left the flat in stockinged feet and festooned three young men with the stew. The men withdrew. He felt compelled to ring a doorbell which said "this one". A young man answered and GW entered, claiming to be a member of the Drug Squad. He ransacked the flat, played a guitar, picked up a Stanley knife, and made the two male occupants take off their trousers. He cut one of the occupants on the arm. He made them walk to a telephone box, and in the process cut the other man on his back. He made the men telephone the police, who arrived and arrested $G W$ when he claimed to be a member of the Drug Squad, was abusive and attempted to drive the police car.

When seen in custody and after admission he maintained that the staff and the interviewing doctor were members of the SAS. He had ideas of reference and passivity feelings. He believed that the sequence of events was part of an SAS training exercise which was being filmed.

Physical examination and investigations were unremarkable. The patient responded well to treatment, but insight never fully returned. In informal out-patient follow-up he insisted on stopping his medication and relapsed within 3 months. His symptoms on readmission were similar to his earlier presentation, but without a recrudescence of the 'Hollywood phenomenon' and without violence to others.

This case suggests that the 'Hollywood phenomenon' is not specific to affective disorders. There is a possibility that the episode was precipitated by amphetamine abuse, although a urine sample was not obtained during his remand in custody and the patient 